\title{
Risks related to drug use among male construction workers
}

\author{
Risco relacionado ao consumo de drogas em \\ homens trabalhadores da construção civil
}

Aroldo Gavioli ${ }^{1}$

Thais Aidar de Freitas Mathias ${ }^{2}$

Robson Marcelo Rossi ${ }^{2}$

Magda Lúcia Félix de Oliveira²

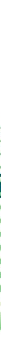

Keywords

Substance-related disorders; Mass screening; Primary care nursing; Occupational health nursing; Workers

Descritores

Transtornos relacionados ao uso de substâncias; Programas de rastreamento; Enfermagem de atenção primária; Enfermagem do trabalho;

Trabalhadores

Submitted

May 6, 2014

Accepted June 23, 2014

\begin{abstract}
Objective: To identify the prevalence of risk related to drug use among workers of a construction company and to evaluate how it relates with sociodemographic variables.

Methods: A cross-sectional study conducted with 418 workers who were given the Alcohol, Smoking and Substance Involvement Screening Test. Multinominal logistic regression was used as a measure of association. Results: Tobacco, alcohol, cannabis, cocaine and inhalants were the most used drugs. Moderate and high risks were related, respectively, to the use of tobacco (32.5\% and 5.7\%), alcohol (26.8\% and 6.9\%), cannabis (2.6\% and $2.4 \%$ ) and cocaine (1.2\% and $0.5 \%)$.

Conclusion: Tobacco and alcohol were the main drugs used by workers. The level of risk related to the use of tobacco, alcohol, cannabis and cocaine were high when compared to that of the general population.

\section{Resumo}

Objetivo: Identificar prevalência do risco relacionado ao consumo de drogas entre trabalhadores de uma empresa de construção civil e avaliar sua associação com variáveis sociodemográficas.

Métodos: Estudo transversal realizado com 418 trabalhadores que responderam ao Alcohol, Smoking and Substance Involvement Screening Test. Utilizou-se a regressão logística multinomial como medida de associação.

Resultados: Tabaco, álcool, maconha, cocaína e inalantes tiveram prevalência de uso elevada. Riscos moderado e elevado estiveram relacionados, respectivamente, aos consumos de tabaco $(32,5 \%$ e 5,7\%), álcool (26,8\% e 6,9\%), maconha (2,6\% e 2,4) e cocaína (1,2\% e 0,5\%).

Conclusão: Tabaco e álcool foram as principais drogas utilizadas pelos trabalhadores. Níveis de risco relacionados ao consumo de tabaco, álcool, maconha e cocaína foram elevados quando comparados aos da população em geral.
\end{abstract}

Corresponding author

Aroldo Gavioli

Mandacarú Avenue, 1590, Maringá, PR,

Brazil. Zip Code: 87083-240

gavioli.aroldo@gmail.com

\section{DOI}

http://dx.doi.org/10.1590/1982-

0194201400077
${ }^{1}$ Hospital Universitário Regional de Maringá, Maringá, PR, Brazil.

2Universidade Estadual de Maringá, Maringá, PR, Brazil.

Conflicts of interest: there are no conflicts of interest to declare. 


\section{Introduction}

The relationship between work and drug use is still little understood in Brazil, where the problem is in fact underreported. ${ }^{(1)}$ Studies point to an increase of violent events in the workplace when there is drug use among workers. ${ }^{(2)}$ Currently, such use is recognized as the main responsible factor for traumatic injury, and the burden imposed on the Brazilian health system by health problems results in elevated social and economic costs. ${ }^{(3,4)}$

Being a common phenomenon of the workplace, drug use results in increased illness, work-related injuries, absenteeism and disability, all of which contribute to reducing productivity. In this context, construction work is a business activity of great importance in the global economic scenario. However, together with its importance in the economy, it also presents a harsh reality regarding working conditions: it is considered one of the most hazardous activities or work worldwide and in Brazil, it is responsible for the highest rates of fatal and non-fatal work-related injuries and of years of potential life lost. ${ }^{(5,6)}$

A case study on severe work-related accidents that happened in the state of Paraná, Brazil, and were recorded in the Brazilian Notifiable Diseases Information System (SINAN, as per its acronym in Portuguese) from 2007 to 2010, found that approximately $14 \%$ of total severe and fatal work-related accidents had happened among construction workers. ${ }^{(7)}$ As responsible for this high rate of work-related accidents among this professional category, we emphasize the elevated level of occupational risks, stress and psychic suffering related to the temporary nature of the job, high staff turnover and precarious work contracts. ${ }^{(6,8)}$

A study that aimed at studying discrimination and social prejudice experienced by construction workers in a metropolitan region of Brazil observed a high prevalence of aggressive, depressive and unhealthy behaviors, such as drug use. Such behavior was associated to the experience of rejection within the context of social discrimination. ${ }^{(9)}$ These findings indicate that construction workers should be the subjects of drug use prevention programs.
In the effort of detecting the level of risk related to drug use among male construction workers, this study aimed at establishing the sociodemographic profile of workers at a construction company in a municipality of the state of Paraná, Brazil. It also aimed at identifying the risk related to such drug use, as well as verifying the association between the risk related to drug use and sociodemographic variables.

\section{Methods}

A cross-sectional study was carried out in 15 work sites of a construction company in the municipality of Maringá in Paraná, a state in the south of Brazil. This municipality is located $426 \mathrm{~km}$ away from the state capital, and had an estimated 385 thousand inhabitants in 2013. ${ }^{(10)}$ Maringá is a medium-sized city with great agricultural production and a developing industrial area (although there are some large industries) and well-developed service and commerce sectors.

The sample comprised 446 men who worked for a construction company and who were directly involved with building construction. Workers were divided into two professional categories: semi-official, better known as laborers, and official, represented by masons, carpenters, reinforcing iron and rebar workers, painters, electricians, finishing workers, and others. Criteria for inclusion were: male workers with a formal work contract, 18 years or older; criteria for exclusion were: absenteeism, refusal to participate in the study, and those who worked on the higher strata of the building, which could pose danger to the researcher and the worker.

Upon receiving the construction company's permission to conduct the study, the researcher was taken to the work sites and introduced to the workers, who were instructed as to the objectives of the study. Once the participants signed the free and informed consent form, the interviews were conducted, which took place between March and June 2012. Interviews were divided into two sections: worker sociodemographic information and the Alcohol, Smoking and Substance Involvement 
Screening Test (ASSIST), by the World Health Organization (WHO).

The following sociodemographic variables were used: age, education level, marital status, skin color, municipality of residence, wages, living conditions, children, time of service in construction, family income, professional category and absenteeism related to drug use.

The ASSIST-WHO instrument was translated and validated in Brazil and consists of eight questions about the use of nine classes of abuse drugs (tobacco, alcohol, cannabis, cocaine, amphetamines, sedatives, inhalants, hallucinogens and opioids). Its questions assess the frequency of use for each abuse drug (in lifetime and in the last 3 months) through the following variables: problems related to drug use; concern of people close to the user; interference with role responsibility; failed attempts to quit or cut down drug use; compulsion to use; and injecting drug use. Each answer corresponds to a score ranging from zero to 8 , and the total sum can vary from zero to $39 .^{(11,12)}$

In terms of defining the risk related to alcohol use, a score from zero to 10 on the test is considered lower risk; from 11 to 26 moderate risk; and when higher than 27 points, it represents high risk up to the progression of dependence. For the other abuse drugs, the scores required for each category are: $0-3$ points; 4-26 points and higher than 27 points, respectively. Thus, a range of problems associated to substance use can be identified, which include acute intoxication, regular use or dependence and high risk of injecting behavior. Scores falling within the intermediate range of the ASSIST indicate the use of hazardous or harmful substances (moderate risk) and the highest scores indicate substance dependence (high risk). ${ }^{(11,12)}$

The data collected were compiled using the IBM Statistical Package for the Social Science $\left(\mathrm{SPSS}^{\circledast}\right)$ software, and the independent variables were dichotomized so that a descriptive statistical analysis and multinominal logistic regression could then be conducted. The objective of this method was to investigate the variables associated to the results (dependent variable: level of risk provided by the ASSIST score, classified as lower, moderate and high, for tobacco, alcohol and illicit drugs). To this end, lower risk was established as the baseline of the dependent variable and backward stepwise regression was used, with a $95 \%$ significance level. For the significant variables in the final model, odds ratio and its respective confidence intervals were adopted as a measure of association. ${ }^{(13)}$

The development of this study complied with ethical guidelines for research involving human beings.

\section{Results}

A total of 418 workers who met the inclusion criteria were interviewed. Twenty-eight workers left the study due to absenteeism (13 workers), leave of absence due to work accidents ( 5 workers), refusal to participate (4 workers) and due to an inaccessible/ hazardous workplace (6 workers).

The mean age of the sample was $41.1( \pm 12.6)$ years, being that the youngest was 18 and the oldest, 74 . Most workers (64.5\%) were in the 36 to 74 year age group. When separated by professional category, the mean age of official workers was 43.1 $( \pm 11.3)$ years and the mode, 52 years. The mean age of semi-official workers was $38.3( \pm 13.6)$ years and the mode, 23 years.

As observed, $73.7 \%$ of workers had up to 8 years of schooling (elementary school), $78.9 \%$ were married or lived with a partner, $54.5 \%$ were white, 96.6 were catholic and 50.2\% from municipalities neighboring Maringá. Most earned less than three minimum monthly wages, were home owners (58.4\%), had children $79.2 \%$, had over 10 years of experience with construction work (79.2\%), with a family income lower than $\mathrm{R} \$ 2,400.00 /$ month $(67.7 \%)$ and were official construction workers (65.1\%). Semi-official workers (laborers) represented $34.9 \%$ of our sample. When asked if they had missed work due to hangovers after a period of drug abuse, $76.3 \%$ replied affirmatively (Table 1 ).

The prevalence of drug use in lifetime was $91 \%$ for alcohol, $72.4 \%$ for tobacco, $18.2 \%$ for cannabis and $6.7 \%$ for cocaine. Inhalant drugs, especially solvents, were mentioned by $5.2 \%$ of the interviewed workers. Other drugs were used by $1.5 \%$ of 
workers, and $5.4 \%$ reported never having used or experimented with any drug of abuse.

Table 1. Construction workers according to sociodemographic variables

\begin{tabular}{|c|c|}
\hline Variables & $\mathrm{n}(\%)$ \\
\hline \multicolumn{2}{|l|}{ Age } \\
\hline $18-35$ & $148(35.4)$ \\
\hline $36-75$ & $270(64.6)$ \\
\hline \multicolumn{2}{|l|}{ Years of schooling } \\
\hline Up to 8 years & $308(73.7)$ \\
\hline More than 8 years & $110(26.3)$ \\
\hline \multicolumn{2}{|l|}{ Marital status } \\
\hline With partner & $330(78.9)$ \\
\hline Without partner & $88(21.1)$ \\
\hline \multicolumn{2}{|l|}{ Skin Color } \\
\hline White & $228(54.5)$ \\
\hline Not white & $190(45.5)$ \\
\hline \multicolumn{2}{|l|}{ Religion } \\
\hline Has a religion & 404(96.6) \\
\hline No religion & $14(3.4)$ \\
\hline \multicolumn{2}{|l|}{ Residency } \\
\hline Other municipalities & $210(50.2)$ \\
\hline Maringá & $208(49.8)$ \\
\hline \multicolumn{2}{|l|}{ Wages } \\
\hline More than 3 minimum monthly wages* & $332(79.4)$ \\
\hline More than 3 minimum monthly wages & 86(20.6) \\
\hline \multicolumn{2}{|l|}{ Living conditions } \\
\hline Home owner & $244(58.4)$ \\
\hline Not home owner & $174(41.6)$ \\
\hline \multicolumn{2}{|l|}{ Children } \\
\hline With children & $331(79.2)$ \\
\hline No children & $87(20.8)$ \\
\hline \multicolumn{2}{|l|}{ Time of service } \\
\hline More than 10 years & 239(57.2) \\
\hline Less than 10 years & $179(42.8)$ \\
\hline \multicolumn{2}{|l|}{ Family income } \\
\hline Less than $\mathrm{R} \$ 2.400,00 /$ month & $283(67.7)$ \\
\hline More than $\mathrm{R} \$ 2.400,00 /$ month & $135(32.3)$ \\
\hline \multicolumn{2}{|l|}{ Professional category } \\
\hline Oficial & $272(65.1)$ \\
\hline Semi-official & $146(34.9)$ \\
\hline \multicolumn{2}{|l|}{ Absenteeism due to drug use } \\
\hline Yes & $319(76.3)$ \\
\hline No & $99(23.7)$ \\
\hline
\end{tabular}

* The minimum monthly wage in 2012 was $\mathrm{R} \$ 622.00$

The data relative to the prevalence of risk associated to drugs of abuse, as classified by the ASSIST-WHO, are presented as follows. When considering tobacco use, $38.2 \%$ of workers were classified as presenting risk for health problems due to substance use, of which $32.5 \%$ presented moderate risk and 5.7\%, high risk. When considering alcohol use, $33.7 \%$ of workers had related risks, of which $26.8 \%$ were moderate, and $6.9 \%$ were high. With respect to illicit drugs, we identified a prevalence of risk associated to cannabis in $5.0 \%$ of workers, of which $2.6 \%$ presented moderate risk and $2.4 \%$, high risk. Furthermore, the prevalence of risk associated to the use of cocaine was identified among $1.7 \%$ of workers, of which $1.2 \%$ presented moderate risk and $0.5 \%$ with high risk (Table 2 ).

Table 2. Construction workers according to classification of risk related to drug use

\begin{tabular}{|c|c|c|}
\hline Drug of abuse* & Related risk & $\mathrm{n}(\%)$ \\
\hline \multirow[t]{3}{*}{ Tobacco } & Lower & $258(61.8)$ \\
\hline & Moderate & $136(32.5)$ \\
\hline & High & $24(5.7)$ \\
\hline \multirow[t]{3}{*}{ Alcohol } & Lower & $277(66.3)$ \\
\hline & Moderate & $112(26.8)$ \\
\hline & High & $29(6.9)$ \\
\hline \multirow[t]{3}{*}{ Cannabis } & Lower & $397(95.0)$ \\
\hline & Moderate & 11(2.6) \\
\hline & High & $10(2.4)$ \\
\hline \multirow[t]{3}{*}{ Cocaine } & Lower & $411(98.3)$ \\
\hline & Moderate & $5(1.2)$ \\
\hline & High & $2(0.5)$ \\
\hline
\end{tabular}

*More than one answer possible

Multinominal logistic regression analysis of moderate and high risk with respect to the worker's sociodemographic variables demonstrated a significantly higher chance of risk related to (in the moderate and high levels) the use of tobacco among workers who reported episodes of absenteeism, not being home owners and belonging to the semi-official category. On the other hand, having less than 10 years of experience with construction work represented a protective factor for the risk related to tobacco use at the moderate and high level. An association was found between belonging to the 36 to 74 age group and moderate level of risk. On one hand, it represents a protective factor for the moderate risk level, and on the other it is associated to increased chances of elevated risk levels (Table 3).

Regarding the risk related to alcohol use, a significant association was also observed between moderate and high risk with work absenteeism, not owning residency and having less than 8 years of schooling (Table 3).

The low number of construction workers who reported the use of illicit drugs found in this study could have influenced the statistical analysis. Thus, the use of cannabis and cocaine were grouped into one category (illicit drugs). Factors associated with higher chances of moderate and high risk related to the use of illicit drugs were absenteeism and belonging to the semi-official professional category (Table 3). 
Table 3. Results of the multinomial logistic regression analysis for the effect of the selected variables on the levels of risk related to drug use

\begin{tabular}{|c|c|c|c|c|c|c|}
\hline \multirow{2}{*}{ Drug of abuse } & \multirow{2}{*}{ Variable } & \multirow{2}{*}{ Category } & \multicolumn{2}{|c|}{ Moderate Risk } & \multicolumn{2}{|c|}{ High Risk } \\
\hline & & & $\mathrm{OR}$ & Cl95\% & $\mathrm{OR}$ & Cl95\% \\
\hline \multirow[t]{5}{*}{ Tobacco } & Absenteeism & Yes & 1.8 & $1.1-3.1$ & 15.1 & $5.2-43$ \\
\hline & Residence & No owned & 2.4 & $1.5-4.0$ & 1.8 & $1.0-4.2$ \\
\hline & Professional category & Semi-official & 1.7 & $1.1-2.8$ & 1.7 & $1.1-2.5$ \\
\hline & Time in profession & $<10$ years & 0.3 & $0.1-0.7$ & 0.2 & $0.0-0.9$ \\
\hline & Age (years) & 36 to 74 & 0.4 & $0.2-0.8$ & 2.3 & $1.3-17.9$ \\
\hline \multirow[t]{3}{*}{ Alcohol } & Absenteeism & Yes & 3.9 & $2.1-7.2$ & 30 & $10-95$ \\
\hline & Residence & No owned & 1.8 & $1.1-3.3$ & 4.3 & $1.5-12.3$ \\
\hline & Schooling & $<8$ years & 2.1 & $1.2-3.7$ & 1.0 & $0.3-2.4$ \\
\hline \multirow[t]{2}{*}{ Illicit drugs } & Absenteeism & Yes & 4.3 & $1.2-14.8$ & 4.1 & $1.1-16.1$ \\
\hline & Professional category & Semi-official & 2.0 & $0.5-7.2$ & 5.1 & $1.1-23.6$ \\
\hline
\end{tabular}

OR - odds ratio; IC95\% - confidence interval of 95\%

\section{Discussion}

The limitation of this study regards the use of data collected in a less than ideal situation, i.e., at work. This situation could have resulted in lack of sincerity, for the theme touches on illegality, and this could have led to an underestimation of data. On the other hand, this method does have its advantages, for the use of standardized instruments helps professionals to establish the limits for defining harmful drug use.

Few Brazilian studies have focused on monitoring the risk related to drug use among workers. Most of them discuss instrument validation, for this technology has only recently been disseminated. Most studies used the CAGE test (an acronym regarding its four questions Cut down, Annoyed by criticism, Guilty and Eye-opener) and the AUDIT, the Alcohol Use Disorders Identification Test, which only investigates alcohol use and dependence. ${ }^{(1)}$ This limits the comparability of prevalence of risk related to drug use in general and among men, particularly construction workers. For this reason, the findings of the present study were compared with national population-based surveys to investigate the risk levels related to other drugs of abuse.

The present study found a high prevalence of lifetime use of tobacco, alcohol, cannabis and cocaine. When comparing the data of our study to that of a household survey on the use of psychotropic drugs conducted in 2006, involving the 108 largest cities in Brazil, the prevalence of lifetime use of alcohol, tobacco, cannabis and cocaine, for men in the South region was 81.7, 56.9, 15.7 and 5.4\%, respectively. ${ }^{(14)}$

Another national survey conducted in 2012 found a prevalence of lifetime use of $7 \%$ for cannabis and $4 \%$ for cocaine. ${ }^{(15)}$ Our findings demonstrate that the lifetime prevalence was greater among construction workers, with the exception of inhalant drugs, which presented similar values. This higher prevalence may be significantly related to the prevalence of regular use, which can progress to continued and long-lasting use. However, the course of evolution followed in experiences with drugs is unknown, indicating that active prevention when drug use is initiated may be the only effective means of prevention. ${ }^{(16)}$

In the present study, alcohol and tobacco were confirmed as the main legal abuse-causing substances; cannabis and cocaine were the main illicit abuse-causing substances. Regarding the prevalence of high levels of risk related to tobacco use, which indicate dependence, although there was an expressive prevalence among workers, it was still lower than the levels found in national surveys. Such surveys observed a prevalence of $12.2 \%$ among men in the South region of Brazil ${ }^{(14)}$ and $16.9 \%$ in Brazil in general. ${ }^{(15)}$ However, taking into consideration individuals with moderate and high levels of risk, which indicate harmful and continued use, the workers in our study presented an expressively higher number than those found in the national surveys, reaching values two to three times higher.

Regarding the prevalence of levels of risk related to the use of alcohol, a lower number of 
workers fulfilled the criteria for dependence (high risk level). The survey for the South region of Brazil found 14.9\% of male individuals to be dependent. ${ }^{(14)}$ On the other hand, the latest national survey in 2012 showed that $10.5 \%$ of individuals of the general population were dependent. ${ }^{(15)}$ However, if we calculate the number of individuals included in the intermediate range of risk (moderate level), we observe that the construction workers present a higher prevalence of harmful and continued alcohol use, reaching two to three times higher values than those found in the national surveys.

With respect to cannabis, the prevalence of high risk (an indicator of dependence) observed was greater than that found among men in the South region of Brazil in 2006, which was $1.1 \%$. (14) However, this prevalence was lower than that observed in the latest survey of 2012, with $4.4 \%$ of male individuals. ${ }^{(15)}$ If we add to this number individuals who score in the intermediate ranges (moderate risk), we observe that, among construction workers, the frequent and continued use of cannabis can be considered higher than that observed in the general population in the surveys mentioned above.

The last national survey on drug use indicated a $2 \%$ prevalence of cocaine dependence among the Brazilian population. ${ }^{(15)}$ Among the construction workers, there was a prevalence of individuals with high risk (dependence indicator) related to the use of this substance lower than that of the general population. However, if we add to this number those individuals who fulfill the criteria for moderate levels of risk (with frequent and continued use), we observe that workers presented a prevalence similar to that found in the national survey.

In another study on the prevalence of drug use among public construction workers of the state of Minas Gerais, ${ }^{(17)}$ there were similarities regarding which were the most used drugs, as well as the high level of use in lifetime. However, the authors did not stratify the data according to risks related to drug use, only according to the frequency of use. Nonetheless, an interesting piece of information was the number of individuals who were classified as needing to be referred to intensive treatment, which were $7.5 \%$, $21.5 \%, 3 \%$ and $2.5 \%$, respectively, for the use of tobacco, alcohol, cannabis and cocaine. When comparing the data, we observe that the workers in our study presented a lower prevalence of continued drug use.

The association between absenteeism and drug use, as was observed in this study, has already been investigated by other studies. Individuals who frequently use alcohol tend to be more absent at work, since such use can result in "hangovers," leading to the absence of partial or full days of work. Moderate and high levels of risk were associated to more days absent due to medical consultations or sick leaves. ${ }^{(18)}$ Absenteeism causes direct effects that are not only felt by employers, but also by other workers who need to take on additional tasks in order to compensate for their absent coworkers. This increased workload harms and overloads these workers. ${ }^{(19)}$

The sociodemographic characteristics of the participants of this study portray the reality of construction workers in Brazil. ${ }^{(5,17)}$ These characteristics include, for example, low education and socioeconomic levels, which in this study were associated to moderate and high risk of tobacco, alcohol and illicit drug use. These characteristics can lead to factors that predispose the individual to a higher risk of involvement and drug use. ${ }^{(2,9)}$

We also found an association between the use of tobacco and illicit drugs with the semi-official category, consisting of younger workers who are still learning their trade. With regards to the use of alcohol and illicit drugs, other studies have shown that younger people tend to drink alcohol in higher levels or with greater risk, and that this group is considered as being at the highest risk for health problems due to alcohol, tobacco and illicit drugs. Thus, the prevalence of use patterns among this demographic segment should be especially monitored. ${ }^{(19,20)}$

An important factor regarding drug use among construction workers is that work sites consist primarily of men, for the work activities 
require conditions considered to be masculine, such as physical strength. We present the hypothesis that men are more solicited for this type of work activity because they are more prone to adventure and risk-taking. Our results corroborate that of other studies that have shown a greater prevalence of drug use and dependence among men. Historically, drug use is a profile associated to the male population, for it is a manner of establishing and maintaining bonds with other men of the same social status. ${ }^{(17,20)}$

A study conducted in Maringá analyzing the profile of hospital morbidity, found the 56.1\% of total hospitalizations consisted of men, primarily young and adults, between the ages of 20 and 59. This study found that mental disorders, $21.5 \%$ and injuries and intoxication, $25.1 \%$ were the main diagnoses for hospitalized men from Maringá in the three year period from 2009 to 2011. ${ }^{(21)}$ These findings are in agreement with the conclusion of the present study that the male population is more vulnerable to some types of mental disorders, which include drug abuse diagnoses and externally caused lesions, frequently related to drug use.

The fact that an expressive number of interviewed workers presented high use in lifetime, continued use and moderate and high risk levels of drug use emphasizes how vulnerable this professional category is to drug use. Such use is considered by the WHO as the main preventable cause of death and years of potential life lost. (22) In this sense, an instrument such as the ASSIST-WHO, which allows for screening the risk related to drug use, easy to apply and interpret, and that allows for brief interventions and result feedback, is an important option for the prevention and early detection of drug use among construction workers. ${ }^{(23)}$

In light of the results of the present study, we observe the importance of this type of screening with standardized instruments by healthcare, nursing, worker's health and primary care teams. This technology can be very useful in the detection, early intervention and, consequently, prevention of this type of drug use among work- ers, for one of the greatest difficulties found by health professionals regarding drug use in the community consists in determining the limits which define drug abuse. ${ }^{(1,11)}$

The results of this study can also help construction companies that wish to implement prevention programs that assess the impact of measures for controlling drug use. In the nursing field, this study indicates the need for the team to consider the working environment as a whole, not only focused on the classic occupational hazards or on the treatment of drug users. Nursing professionals must also consider the male population in the work place and their actions, which will help reduce drug use and increase safety and health, not only with regards to construction work, but also in the most diverse occupational realities. It is necessary for the nursing professional to be aware of the morbidity profile of the male population, in order to raise more awareness among adult men about the benefits of acting towards disease prevention. ${ }^{(21,24)}$

\section{Conclusion}

Tobacco and alcohol were the main drugs used among workers. The level of risk related to the use of tobacco, alcohol, cannabis and cocaine was high when compared to those of the general population.

\section{Acknowledgements}

The authors thank the workers and the Construction Worker Labor Union of Maringá, SINTRACON, and the staff of the Committee for Incentive of Formality in Civil Construction, especially Ms. Mary and all of the construction workers.

\section{Collaborations}

Gavioli A contributed with the project conception, development of the research and drafting of the article. Rossi RM collaborated with the sampling plan, statistical analysis and data interpretation. Mathias TAF and Oliveira MLF contributed with the critical review of its intellectual content and the final approval of the version to be published. 


\section{References}

1. Rocha PR, David HM. Questionários sobre 0 uso de álcool e drogas entre trabalhadores: revisão da literatura. SMAD. 2011;7(2):107-16.

2. Corrao CR, Fratarcangeli M, Capitanelli I. Alcohol use in the construction industry: results of a survey. G Ital Med Lav Ergon. 2012; 34(Supl 3):507-10. Italian.

3. Furegato AR. Alcohol y otras drogas: acciones en busca de soluciones. Revista Latinoam Enferm. 2011; 19(Spe):663-4. Spanish.

4. Marangoni SR, Oliveira ML. Use of crack by multiparou socially vulnerable woman: a life history. Cienc Cuid Saude. 2012;11(1):16672. Portuguese.

5. Cockell FF. Da enxada à colher de pedreiro: trajetórias de vulnerabilidade social na construção civil. Interface - Comunicação, Saúde, Educação. 2010; 4(32):233.

6. Araujo JS, Silva SE, Conceição VM, Santana ME, Souza RF. A bebida alcoólica no contexto laboral: um diálogo mediado pelas representações sociais. Tempus Actas de Saúde Coletiva. 2012; 6(3):217-33.

7. Scussiato LA, Sarquis LM, Kirchhof AL, Kalinke LP. [ Epidemiological profile of serious accidents at work in the State of Paraná, Brazil, 20072010]. Epidemiol Serv Saúde. 2013; 22(4):621-30. Portuguese.

8. Iriart JA, Oliveira RP, Xavier SS, Costa AM, Araújo GR, Santana VS. Representações do trabalho informal e dos riscos à saúde entre trabalhadoras domésticas e trabalhadores da construção civil. Ciênc Saúde Coletiva. 2008;13(1):165-74.

9. Borges LO, Peixoto TP. Ser operário da construção civil é viver a discriminação social. Rev Psicol Organ Trab. 2011; 11(1):21-36.

10. Instituto Brasileiro de Geografia e Estatística (IBGE). Paraná, Maringá [Internet]. Brasília, DF: IBGE Cidades, Maringá; 2013 [citado 2014 Mai 2]. Disponível em: http://cidades.ibge.gov.br/xtras/perfil. php?codmun $=411520$.

11. Henrique IF, De Micheli D, Lacerda RB, Lacerda LA, Formigoni ML. VValidation of the Brazilian version of Alcohol, Smoking and Substance Involvement Screening Test (ASSIST).] Rev Assoc Med Bras. 2004; 50(2):199-206. Portuguese.

12. Humeniuk R, Ali R, Babor TF, Farrell M, Formigoni ML, Jittiwutikarn J, et al. Validation of the Alcohol, Smoking And Substance Involvement Screening Test (ASSIST). Addiction. 2008; 103(6):1039-47.
13. Agresti A. An introduction to categorical data analysis. 3rd ed. New York: John Wiley And Sons; 2012.

14. Carlini EA, Galduróz JC, Silva AA, Noto AR, Fonseca AM, Carlini CM, et al. II levantamento domiciliar sobre 0 uso de drogas psicotrópicas no Brasil: estudo envolvendo as 108 maiores cidades do país. In: Centro Brasileiro de Informações sobre Drogas Psicotrópicas. Região Sul. São Paulo, SP: UNIFESP; 2006.

15. Laranjeira R, Madruga CS, Pinsky I, Caetano R, Mitsuhiro S. II LENAD Levantamento nacional de álcool e droga: tendências entre 2006/2012 [Internet]. São Paulo: INPAD; 2013[citado 2014 Mai 2]. Disponível em: http://inpad.org.br/lenad.

16. Milanés ZC, Gómez-Bustamente E. Lifetime prevalence of drugs use in adolescents from Cartagena, Colombia. Invest Educ Enferm. 2012; 30(2):224-30

17. Costa EE, Viana DM, Silva AG, Machado RM. Padrão de uso de álcool e outras drogas por trabalhadores de obras públicas. Rev Baiana Enferm. 2013; 21(1):76-81.

18. Bacharach SB, Bamberger P, Biron M. Alcohol consumption and workplace absenteeism: The moderating effect of social support. J Appl Psychol. 2010; 95(2):334-48.

19. Dale CE, Livingston MJ. The burden of alcohol drinking on co-workers in the australian workplace. Med J Aust. 2010; 193(3):138-40.

20. Abreu AM, Jomar RT, Souza MH, Guimarães RM. Consumo nocivo de bebidas alcoólicas entre usuários de uma Unidade de Saúde da Família. Acta Paul Enferm. 2012; 25(2):291-5.

21. Arruda GO, Molena-Fernandes CA, Mathias TA, Marcon SS. Hospital morbidity in a medium-sized city: differentials between men and women. Rev Latinoam Enferm. 2014; 22(1):19-27.

22. World Health Organization (WHO). Global strategy to reduce the harmful use of alcohol. Geneve: WHO; 2010.

23. Humeniuk R, Henry-Edwards S, Ali R, Poznyak V, Monteiro MG (org.). The Alcohol, Smoking and Substance Involvement Screening Test (ASSIST): manual for use in primary care. Geneva: WHO; 2010.

24. Scheffer M, Almeida RMM. Alcohol consumption and differences between men and women: impulsive behavior, cognitive and neurochemistry aspects. Rev Neuropsicol Latinoam. 2010; 2(3):111. 